\title{
Fertilization influence on biomass yield and nutrient uptake of sweet corn in potentially hardsetting soil under no tillage
}

\author{
Ronley C. Canatoy ${ }^{1,2^{*}}$ (D) and Nonilona P. Daquiado ${ }^{1}$
}

\begin{abstract}
Background: Hardsetting soils are considered problem soils due to its behavior of becoming hard and unbearable to cultivate not until rewetted. Few investigations were conducted in this kind of problem soil; hence, information about biomass yield and nutrient uptake is still elusive. This study investigated the impact of potentially hardsetting soil on the biomass yield and nutrient uptake of sweet corn under no-tillage cultivation system with varying fertilization treatments.

Results: The application of full NPK $+1 \mathrm{Mg} \mathrm{ha}^{-1} \mathrm{VC}$ increased stover and grain yield by $26-106 \%$ and $11-135 \%$, respectively. Approximately $64 \%$ and $112 \%$ of sweet corn stover and grain yield increased when treated with full NPK. Highly significant quadratic relationship $(P<0.001)$ was revealed between total biomass yield and nutrient uptake of sweet corn, implying that $98-99 \%$ of the variation in total biomass could be elucidated by its nutrient uptake. Further, this indicated the suitability of nutrient uptake function that could be used as an estimate in the progression of total biomass accumulation. The application of full NPK showed statistically significant $(P<0.001)$ nitrogen and phosphorus use efficiency across treatments. The soil in the experimental area was a potentially hardsetting soil due to its rapid soil strength development at least 4 days from wetting. This implies that with continued use, proper soil management must be implemented like reduced tillage and organic matter application to facilitate structure formation and binding of soil particles by labile fraction in organic matter.

Conclusion: Application of organic amendment in combination with inorganic fertilizer could be a sustainable production strategy on sweet corn production system in potentially hardsetting soil under no tillage through enhanced nutrient uptake and biomass accumulation.
\end{abstract}

Keywords: Potentially hardsetting soil, Vermicompost, Nutrient uptake, No tillage, Zea mays L. Saccharata

\section{Background}

Hardsetting is a phenomenon that happens in numerous soils globally including arid tropical, semiarid, and Mediterranean areas (Mullins 1999). It is considered an inherent behavior of soil that is characterized by the development of high mechanical strength as it dries and disintegrates substantial strengths when wetted (Mullins

\footnotetext{
*Correspondence: rcanatoy@gmail.com

${ }^{1}$ Department of Soil Science, College of Agriculture, Central Mindanao University, Maramag, Philippines

Full list of author information is available at the end of the article
}

et al. 1987, 1990). The chemical, physical and mineralogical properties of soils are prime indicators by which soil hardsetting behavior could be attributed (Mullins et al. 1990; Young et al. 1991). Poor soil properties lead to deterioration in soil quality, which strongly negatively affects crop growth and yield performance (Ghosh and Devi 2019).

The global food production has never stopped on increasing due to the skyrocketing demand, and by 2050 it is projected that world food demand may escalate to approximately $25-70 \%$ (Hunter et al. 2017). The demand for food as a basic necessity has been a challenge to 
every farmer to increase productivity, especially in the twenty-first century (Bodirsky et al. 2015). However, it is important to note that continual crop production without replenishing the nutrients removed by crops during its entire life cycle would deplete the inherent fertility level of soil (Tan et al. 2005). To maintain soil productivity, it is important to monitor the overall health condition of soil (Seleiman and Kheir 2018; Tahat et al. 2020). The periodic addition of organic amendment has long been practiced historically and is highly recommended due to its capacity to increase soil organic carbon (SOC) stock (Scotti et al. 2015; Ren et al. 2018). When organic amendment is added, carbon $(\mathrm{C})$ and other essential nutrients like nitrogen $(\mathrm{N})$, phosphorus $(\mathrm{P})$, and potassium $(\mathrm{K})$ are supplied, which are highly essential for growing crops to complete its life cycle (Diacono and Montemurro 2010).

Efficient fertilization is one basic nutrient management schemes that holds huge importance in crop production as it serves as a gateway into increasing crop productivity and nutrient use efficiency (Yousaf et al. 2017; Seleiman et al. 2021). Furthermore, the addition of fertilizer determines the amount of nutrients that plants could access, as native nutrients present in the soil would not last for long-term crop production (Selim 2020). Addition of inorganic fertilizer, which is chemically synthesized and organic fertilizer in the form of livestock manure, green manure, crop residues and composts, has long been debated as to which promotes and preserves soil health in the long run (Seleiman et al. 2012, 2020; Geng et al. 2019). However, organic amendments are found effective to improve the physicochemical and microbiological properties of the soil, which are important in increasing the productivity and quality of soil (Liu et al. 2017). The relationship between crop yield and nutrient uptake, such as nutrient internal efficiency (IE) and plant nutrient ratio (e.g., $\mathrm{N} / \mathrm{P}$ and $\mathrm{N} / \mathrm{K}$ ), is widely used to assess nutrient limitations in crop fields (Jiang et al. 2017; Zhao et al. 2020). The law of limiting factors is considered one of the most important principles of plant nutrition. This law states that the factor with very limited supply can hamper yield or plant growth. Dry matter accumulation is directly related to the nutrient uptake of plants as these nutrients serve as building blocks for growth and physiological processes (Gaspar et al. 2018; Seleiman and Abdelaal 2018).

No tillage is a soil cultivation system in which seeds are deposited directly into untilled soil. It is regarded as a component of sustainable land management and better land husbandry approaches (Sastre et al. 2018). Numerous investigations have reported that reduction in soil cultivation in relation to conservation or no tillage can significantly alter the distribution of plant available nutrients within the surface layer of soil (Singh et al. 2020).
Hence, it is important to know the growth performance of crop under this kind of tillage system (Seleiman et al. 2019; Ding et al. 2021).

This study further investigated the impact of potentially hardsetting soil on the biomass yield and nutrient uptake of sweet corn in a no-tillage cultivation system under varying fertilization. Findings of this study would help better understand the biomass yield performance and nutrient uptake of sweet corn in potentially hardsetting soil under no tillage.

\section{Methods}

\section{Location and description of experimental area, soil characteristics, and treatments}

The field investigation took place at Maramag, Philippines $\left(7.76^{\circ} \mathrm{N} 125^{\circ} \mathrm{E}, 276 \mathrm{~m}\right.$ above sea level) (Fig. 1). The experimental site belongs to soil order Alfisol of soil great group Hapludalfs. The parent material are igneous materials that are mainly basalt and andesite. The soil at the experimental area is classified as La Castellana clay (Mariano et al. 1955; PCARRD 2006). Soil samples were collected at random from 0 to $15 \mathrm{~cm}$. Soil analytical data indicated that soil had $36 \%$ silt, $30 \%$ sand, and $34 \%$ clay which is clay loam. Bulk density of $1.21 \mathrm{~g} \mathrm{~cm}^{-3}$, strongly acidic reaction of $\mathrm{pH} 5.52$, marginal soil organic matter (SOM) of $3.90 \%$, medium extractable P of $17.37 \mathrm{mg} \mathrm{kg}^{-1}$ and high exchangeable $\mathrm{K}$ of $1.11 \mathrm{cmol}_{\mathrm{c}} \mathrm{kg}^{-1}$. Hence, fertilizer-recommended rate (inorganic fertilizer) was $70-50-0 \mathrm{~kg} \mathrm{ha}^{-1}$ of N, $\mathrm{P}_{2} \mathrm{O}_{5}$ and $\mathrm{K}_{2} \mathrm{O}$.

The experiment was laid out in a randomized complete block design with 6 treatments and 3 replicates. Treatments were: no fertilizer, recommended $\mathrm{N}-\mathrm{P}_{2} \mathrm{O}_{5}-\mathrm{K}_{2} \mathrm{O}$ (Full NPK), $2 \mathrm{Mg} \mathrm{ha}^{-1}$ vermicompost (VC), $1 / 2$ recommended $\mathrm{N}-\mathrm{P}_{2} \mathrm{O}_{5}-\mathrm{K}_{2} \mathrm{O}(1 / 2 \mathrm{NPK})+1 \mathrm{Mg} \mathrm{ha}^{-1} \mathrm{VC}, 1 / 2$ recommended $\mathrm{N}-\mathrm{P}_{2} \mathrm{O}_{5}-\mathrm{K}_{2} \mathrm{O}(1 / 2 \mathrm{NPK})+2 \mathrm{Mg} \mathrm{ha}^{-1} \mathrm{VC}$ and recommended $\mathrm{N}-\mathrm{P}_{2} \mathrm{O}_{5}-\mathrm{K}_{2} \mathrm{O}$ (Full NPK) $+1 \mathrm{Mg} \mathrm{ha}^{-1} \mathrm{VC}$.

\section{Experiment installation and cultural practices}

The field was cleared from plant residues and sprayed with herbicide for existing weeds. The total land area used in the experiment was $463.75 \mathrm{~m}^{2}(35 \mathrm{~m} \times 13.25 \mathrm{~m})$. It was divided into three (3) blocks, and each had an area of $131.25 \mathrm{~m}^{2}$. Within every block installed the six (6) experimental plots. A one-meter space between blocks and experimental plots served as alleyways.

The VC was bought from a vermi farm in Valencia City, Philippines. The VC had a pH of 6.52 and an organic matter content of $324.5 \mathrm{~g} \mathrm{~kg}^{-1}$. In addition, it had total $\mathrm{N}$ of $28.2 \mathrm{~g} \mathrm{~kg}^{-1}$, total P of $11.4 \mathrm{~g} \mathrm{~kg}^{-1}$ and total $\mathrm{K}$ of $4.5 \mathrm{~g} \mathrm{~kg}^{-1}$. The VC was manually incorporated in plots a day before seeding operation. Half of $\mathrm{N}$ and full of $\mathrm{P}$ were applied as basal fertilizer, and remaining $\mathrm{N}$ was on $33^{\text {rd }}$ day after seeding. 


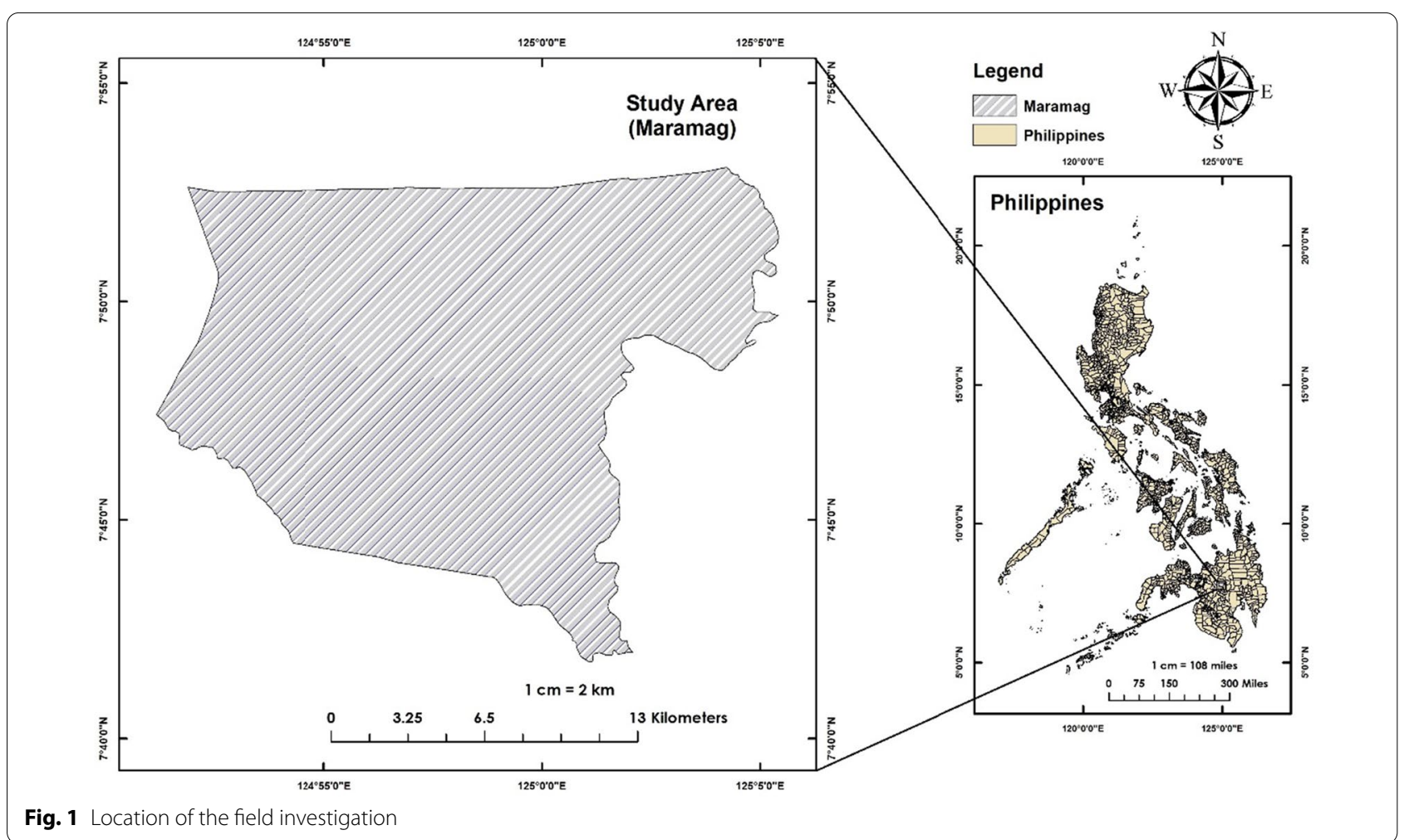

Since no furrows were made to serve as guide for planting, line was drawn using a stick serving as demarcation in sowing the seeds. Dibble planting method was implemented to all the experimental plots (Harman 2016). Planting distance was $0.25 \mathrm{~m}$ between hills and $0.75 \mathrm{~m}$ between rows. One row in all sides of the plot served as guard rows, while inner rows served as data rows where biomass yield were obtained.

Ten sample plants were randomly collected from data rows in each experimental plot. A white paper sheet was placed inside a plastic cellophane and attached to each data plants that served as distinguishing mark that guided during data collection. At physiological maturity, the 10 tagged plants were harvested and weighed. The ears were detached from the stover. Grains were grated from the corn cob, and stover was chopped at $5 \mathrm{~cm}$ long. All plant biomass were air-dried for a week and thereafter oven-dried at $70{ }^{\circ} \mathrm{C}$ for $2-3$ days. Oven-dried biomass samples were ground using Wiley mill and stored in labeled plastic containers with cover for analyses.

\section{Soil, VC, and plant tissue analyses}

The SOM was determined using the Walkley-Black method as outlined by PCARRD (1991) and soil pH following the methods reported by Biddle (1997). Available $\mathrm{P}$ was quantified using Bray $\mathrm{P}_{2}$ as illustrated by Sherrell (1970) and exchangeable $\mathrm{K}$ using $1 \mathrm{~N}$ ammonium acetate solution determined using flame photometer. Total $\mathrm{N}$ concentration in VC and plant samples was measured using micro-Kjeldahl's apparatus as illustrated by Ogg (1960). Vanadate-molybdate reagent was used to determine total $\mathrm{P}$ concentration in $\mathrm{VC}$ and tissue samples using UV-visible spectrophotometer. Total $\mathrm{K}$ in VC and plant tissues was done using the dry ashing method and determined using flame photometer after calibrating with $\mathrm{K}$ standard solutions. The nutrient uptake of sweet corn plants was calculated following the equation of Sharma et al. (2012) below:

$$
\begin{aligned}
& \text { NutrientuptakeofNorPorK }\left(\mathrm{kgha}^{-1}\right) \\
& =\frac{\text { Nor\%Por\%K } \times \text { drymatterweight }\left(\mathrm{kgha}^{-1}\right)}{100}
\end{aligned}
$$

Below are the following formula used to evaluate nutrient harvest index $\left(\mathrm{HI}_{\mathrm{N} / \mathrm{P}}\right)$, internal nutrient efficiency $\left(\mathrm{IE}_{\mathrm{N} / \mathrm{P}}\right)$, reciprocal internal nutrient efficie

ncy $\left(\operatorname{RIE}_{\mathrm{N} / \mathrm{P}}\right)$, agronomic nutrient use efficiency $\left(\mathrm{AE}_{\mathrm{N} / \mathrm{P}}\right)$, partial nutrient factor productivity $\left(\mathrm{PFP}_{\mathrm{N} / \mathrm{P}}\right)$, physiological nutrient efficiency $\left(\mathrm{PE}_{\mathrm{N} / \mathrm{P}}\right)$, and recover efficiency of applied nutrient $\left(\mathrm{RE}_{\mathrm{N} / \mathrm{P}}\right)$, respectively (Che et al. 2015; Jiang et al. 2017): 


$$
\begin{aligned}
& \operatorname{IE}_{\mathrm{N} / \mathrm{P}}\left(\mathrm{kg} \mathrm{kg}^{-1}\right)=\frac{\text { grain yield }}{\text { plant } \mathrm{N} / \mathrm{P} \text { uptake }} \\
& \operatorname{RIE}_{\mathrm{N} / \mathrm{P}}\left(\mathrm{kg} \mathrm{Mg}^{-1}\right)=\frac{\text { plant } \mathrm{N} / \mathrm{P} \text { uptake }}{\text { grain yield }} \\
& \mathrm{HI}_{\mathrm{N} / \mathrm{P}}\left(\mathrm{kg} \mathrm{kg}^{-1}\right)=\frac{\mathrm{N} / \mathrm{P} \text { accumulation in grain }}{100} \\
& \operatorname{PFP}_{\mathrm{N} / \mathrm{P}}\left(\mathrm{kg} \mathrm{kg}^{-1}\right)=\frac{\text { grain yield of } \mathrm{N} / \mathrm{P} \text { applied }}{\mathrm{N} / \mathrm{P} \text { applied to soil }}
\end{aligned}
$$$$
\mathrm{AE}_{\mathrm{N} / \mathrm{P}}\left(\mathrm{kg} \mathrm{kg}^{-1}\right)=\frac{\text { grain yield of } \mathrm{N} / \mathrm{P} \text { applied }- \text { grain yield of N/P omission }}{\mathrm{N} / \mathrm{P} \text { applied to soil }}
$$$$
\mathrm{PE}_{\mathrm{N} / \mathrm{P}}\left(\mathrm{kg} \mathrm{kg}^{-1}\right)=\frac{\text { grain yield of } \mathrm{N} / \mathrm{P} \text { applied }- \text { grain yield of } \mathrm{N} / \mathrm{P} \text { omission }}{\mathrm{N} / \mathrm{P} \text { uptake of } \mathrm{N} / \mathrm{P} \text { applied to soil }-\mathrm{N} / \mathrm{P} \text { uptake of } \mathrm{N} / \mathrm{P} \text { omission }}
$$$$
\mathrm{RE}_{\mathrm{N} / \mathrm{P}}\left(\mathrm{kg} \mathrm{kg}^{-1}\right)=\frac{\mathrm{N} / \mathrm{P} \text { uptake of N/P applied }-\mathrm{N} / \mathrm{P} \text { uptake of N/P omission }}{\mathrm{N} / \mathrm{P} \text { applied to soil }}
$$

\section{Stover and grain biomass yield of sweet corn}

In a potentially hardsetting soil, the application of NPK and VC and their combinations revealed significant $(P<0.05)$ influence on the biomass yield of sweet corn (Fig. 3). In full NPK-treated plot, stover biomass

average monthly distribution recorded 5 years ago of $241.7 \mathrm{~mm}$. However, the average temperature was higher the day after seeding until the harvesting stage. In addition, a gradual increase in air temperature was observed throughout the investigation period. Papplied to soil

\section{Soil strength development determination}

Soil samples were placed in a $15-\mathrm{cm}$-deep and $20-\mathrm{cm}$ diameter basin. Two treatments employed, puddled and non-puddled and replicated 4 times. All experimental units were saturated with water. Puddled experimental units were stirred using glass stirring rod. The purpose of stirring was to simulate the plowing process practiced in the field. While non-puddled experimental units left untouched after water saturation, soil strength was measured and monitored for 10 days using a handheld penetrometer (Daquiado 1998).

\section{Statistical analysis}

Statistical analyses were done using the Statistical Tool for Agricultural Research (STAR) software for the analysis of variance (ANOVA). Tukey's honestly significant difference (HSD) test was used at $P<0.05$ level of significance to test the differences among treatment means in each parameter (Moe et al. 2019).

\section{Results}

Precipitation and air temperature oscillations during sweet corn cultivation

The average monthly precipitation during the course of sweet corn cultivation was $15.3 \mathrm{~mm}$, and the average temperature was $32.8{ }^{\circ} \mathrm{C}$ (Fig. 2). This average monthly precipitation was very low compared to the annual increased by $64 \%$ compared to no-fertilizer application. The application of $2 \mathrm{Mg} \mathrm{ha}^{-1} \mathrm{VC}$ yielded significantly $(P<0.05)$ lower than full NPK of approximately $2.33 \mathrm{Mg} \mathrm{ha}^{-1}$ stover. Stover yield in plots treated with $1 / 2$ $\mathrm{NPK}+1 \mathrm{Mg} \mathrm{ha}^{-1} \mathrm{VC}$ was comparably $(P>0.05)$ lower than $1 / 2 \mathrm{NPK}+2 \mathrm{Mg} \mathrm{ha}^{-1} \mathrm{VC}$ by around $18.3 \%$. This means that $1 \mathrm{Mg} \mathrm{ha}^{-1} \mathrm{VC}$ can increase stover yield by $1.3 \mathrm{Mg} \mathrm{ha}^{-1}$ provided with the same level of inorganic fertilizer application; however, increase was not significant. In treatment $1 / 2 \mathrm{NPK}+2 \mathrm{Mg} \mathrm{ha}^{-1}, \mathrm{VC}$ yielded $31 \%$ higher stover than $2 \mathrm{Mg} \mathrm{ha}^{-1} \mathrm{VC}$; however, the increase was not statistically different at $5 \%$ level of significance. Highest stover yield was obtained from plot treated with full NPK $+1 \mathrm{Mg} \mathrm{ha}^{-1} \mathrm{VC}$ of approximately $9.6 \mathrm{Mg} \mathrm{ha}^{-1}$; however, this stover yield was comparable $(P>0.05)$ with full NPK application. In comparison with no-fertilizer application, the addition application of full $\mathrm{NPK}+1 \mathrm{Mg} \mathrm{ha}^{-1} \mathrm{VC}$ yielded around $106 \%$ higher stover $(P<0.05)$.

In terms of grain biomass as illustrated in Fig. 3, the application of $1 / 2 \mathrm{NPK}+1 \mathrm{Mg} \mathrm{ha}^{-1} \mathrm{VC}$ and $1 / 2$ $\mathrm{NPK}+2 \mathrm{Mg} \mathrm{ha}^{-1} \mathrm{VC}$ increased around $0.24 \mathrm{Mg}$ and $0.62 \mathrm{~kg} \mathrm{ha}^{-1}$ than with no-fertilizer treatment, respectively. However, the increase was not statistically different at $5 \%$ level of significance. The application of full NPK was statistically higher $(P<0.05)$ than $2 \mathrm{Mg} \mathrm{ha}^{-1}$ VC treatment of around 61.6\%. However, full NPK was 


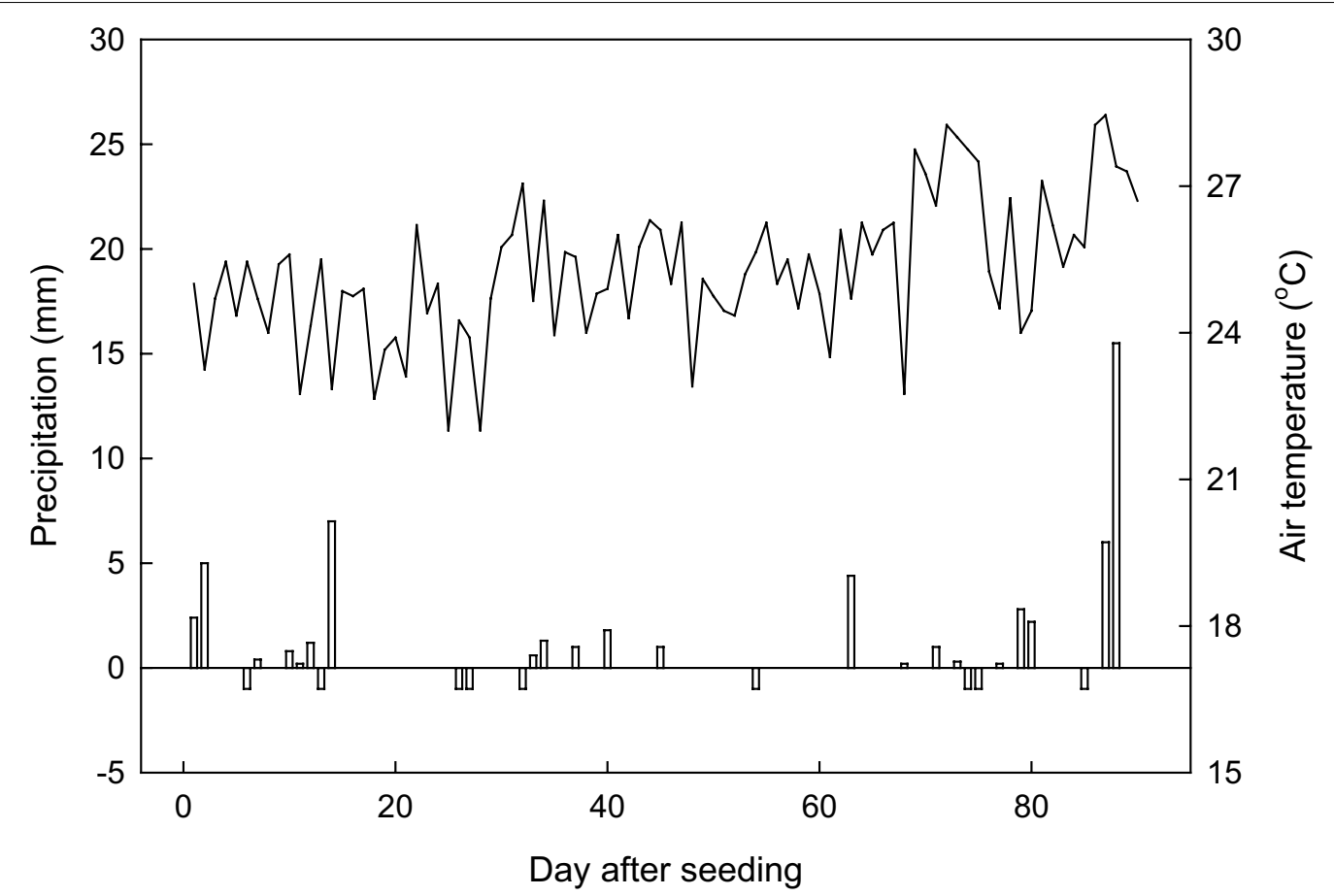

Fig. 2 Changes in precipitation and air temperature during sweet corn cultivation

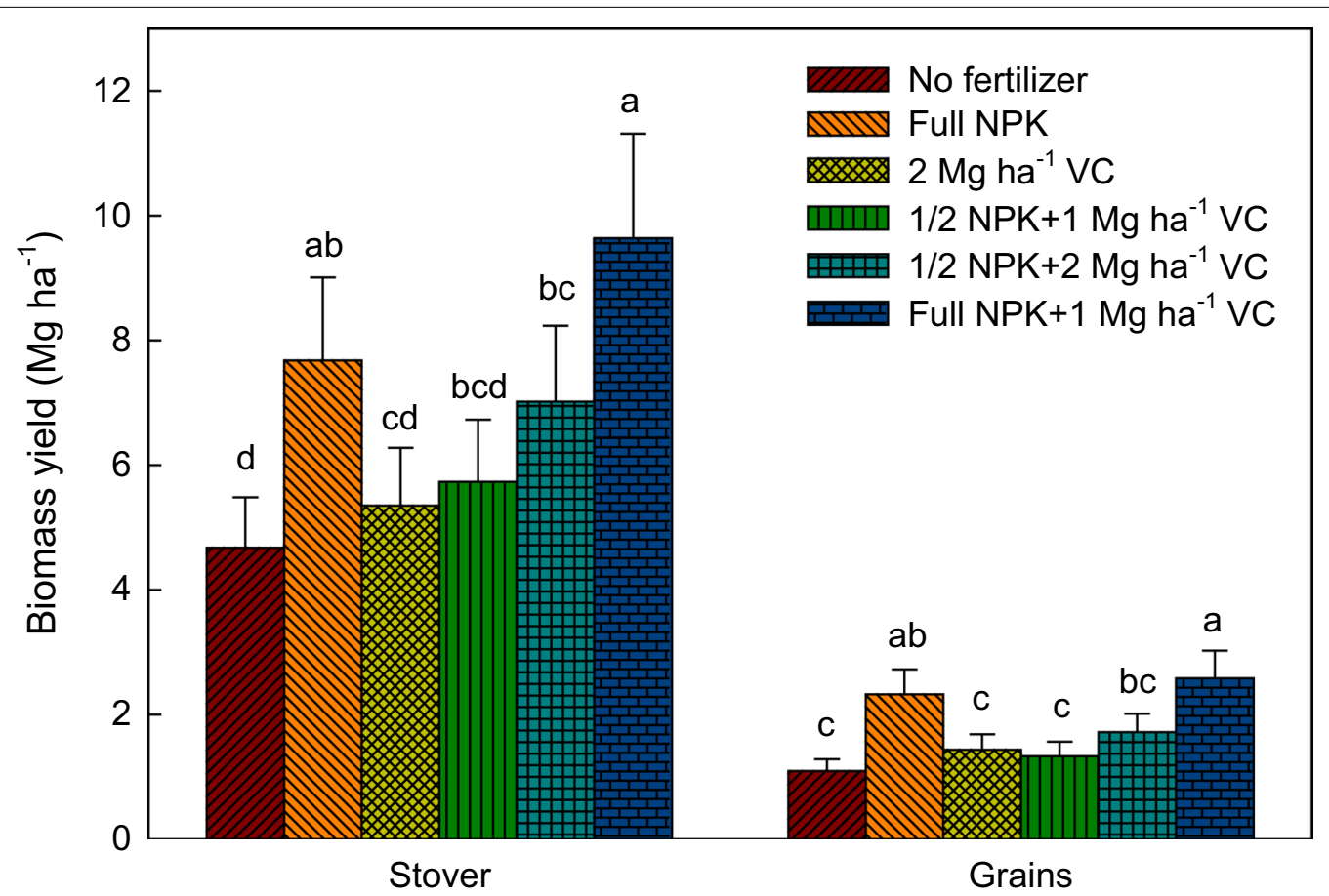

Fig. 3 Stover and grain biomass yield of sweet corn as influenced by different fertilization. Vertical bars indicate standard deviations $(n=3)$ 
not significantly different with full NPK $+1 \mathrm{Mg} \mathrm{ha}^{-1} \mathrm{VC}$ although grain yield in full NPK was $10 \%$ lower. Moreover, full NPK $+1 \mathrm{Mg} \mathrm{ha}^{-1} \mathrm{VC}$ application significantly increased by $93 \%$ over $1 / 2 \mathrm{NPK}+1 \mathrm{Mg} \mathrm{ha}^{-1} \mathrm{VC}$. In comparison with no-fertilizer treatment, the application of full NPK $+1 \mathrm{Mg} \mathrm{ha}^{-1} \mathrm{VC}$ increased grain biomass significantly $(P<0.05)$ by around $135.1 \%$.

\section{Nitrogen uptake of sweet corn in stover and grain}

The stover $\mathrm{N}$ uptake of sweet corn was significantly $(P<0.05)$ affected by the application of inorganic fertilizer NPK, VC and their combinations under potentially hardsetting soil as shown in Fig. 4. The application of $2 \mathrm{Mg} \mathrm{ha}^{-1} \mathrm{VC}$ increased stover $\mathrm{N}$ uptake by

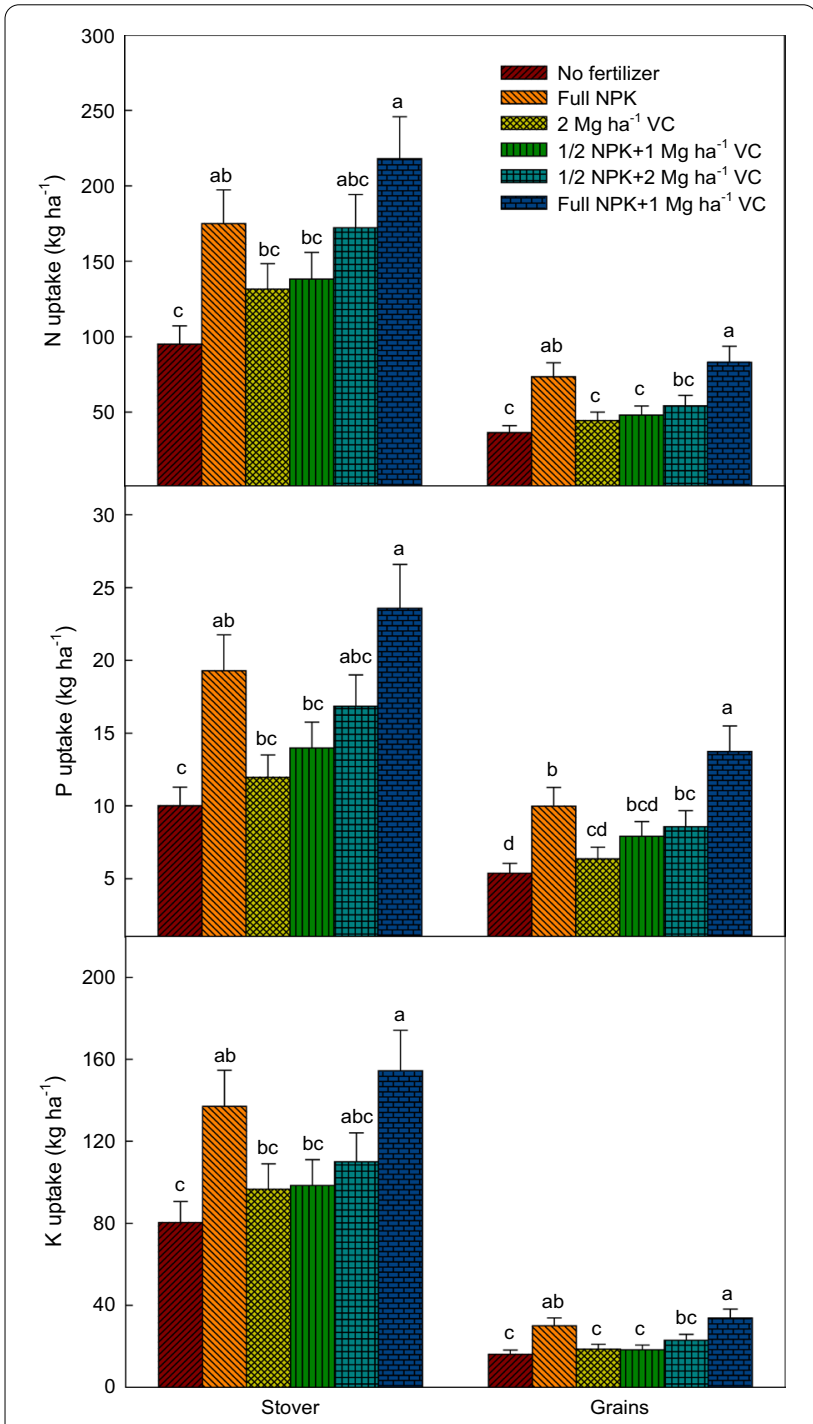

Fig. $4 \mathrm{~N}, \mathrm{P}$, and K uptake of sweet corn as influenced by different fertilization. Vertical bars indicate standard deviations $(n=3)$ approximately $38.4 \%$ compared with no-fertilizer application; however, difference was not statistically significant $(P>0.05)$. In comparison with $1 / 2 \mathrm{NPK}+1 \mathrm{Mg} \mathrm{ha}^{-1}$ $\mathrm{VC}$, stover N uptake in full NPK and $1 / 2 \mathrm{NPK}+2 \mathrm{Mg} \mathrm{ha}^{-1}$ VC-treated plots increased comparably $(P>0.05)$ by around 36.8 and $34.1 \mathrm{~kg} \mathrm{ha}^{-1}$, respectively. Stover $\mathrm{N}$ uptake in treatment full NPK $+1 \mathrm{Mg} \mathrm{ha}^{-1} \mathrm{VC}$ was $24.6 \%$ and $26.6 \%$ higher than full NPK and $1 / 2 \mathrm{NPK}+2 \mathrm{Mg} \mathrm{ha}^{-1}$ $\mathrm{VC}$, respectively. However, the observed increase was not significantly different at $5 \%$ level of significance. Comparing the stover $\mathrm{N}$ uptake of $2 \mathrm{Mg} \mathrm{ha}^{-1} \mathrm{VC}$ and $1 / 2$ $\mathrm{NPK}+2 \mathrm{Mg} \mathrm{ha}^{-1} \mathrm{VC}$, the latter increased by approximately $40.6 \mathrm{~kg} \mathrm{ha}^{-1}$ than the former, but no statistical difference was noted $(P>0.05)$. Conversely, the application of full NPK $+1 \mathrm{Mg} \mathrm{ha}^{-1} \mathrm{VC}$ significantly increased $(P<0.05)$ by $58 \%$ and $66 \%$ over $1 / 2 \mathrm{NPK}+1 \mathrm{Mg} \mathrm{ha}^{-1} \mathrm{VC}$ and $2 \mathrm{Mg} \mathrm{ha}^{-1} \mathrm{VC}$, respectively.

Similarly, as depicted in Fig. 4 grain $\mathrm{N}$ uptake was observed lowest in no-fertilizer application across treatments. However, it was noted to have no significant difference with the application of $2 \mathrm{Mg} \mathrm{ha}^{-1} \mathrm{VC}$ although the application of $\mathrm{VC}$ increased grain $\mathrm{N}$ uptake by approximately $8 \mathrm{~kg} \mathrm{ha}^{-1}$. In addition, $\mathrm{N}$ uptake from no-fertilizer application was comparable $(P>0.05)$ with plots applied with $1 / 2 \mathrm{NPK}+1 \mathrm{Mg} \mathrm{ha}^{-1} \mathrm{VC}$ and $1 / 2$ $\mathrm{NPK}+2 \mathrm{Mg} \mathrm{ha}^{-1} \mathrm{VC}$. Highest $\mathrm{N}$ uptake was observed in full NPK $+1 \mathrm{Mg} \mathrm{ha}^{-1} \mathrm{VC}$ treatment, which was statistically highest $(P<0.05)$ across treatments except with full NPK application. Moreover, full NPK application increased by around $65 \%$ and $53 \%$ over $2 \mathrm{Mg} \mathrm{ha}^{-1} \mathrm{VC}$ and $1 / 2 \mathrm{NPK}+1 \mathrm{Mg} \mathrm{ha}^{-1} \mathrm{VC}$, respectively. Conversely, the $6.2 \mathrm{~kg} \mathrm{ha}^{-1}$ grain $\mathrm{N}$ uptake difference between treatments $1 / 2 \mathrm{NPK}+1 \mathrm{Mg} \mathrm{ha}^{-1} \mathrm{VC}$ and $1 / 2 \mathrm{NPK}+2 \mathrm{Mg} \mathrm{ha}^{-1} \mathrm{VC}$ was statistically not significant $(P<0.05)$. Full NPK application resulted to grain $\mathrm{N}$ uptake of $73.4 \mathrm{~kg} \mathrm{ha}^{-1}$; however, the application of full NPK $+1 \mathrm{Mg} \mathrm{ha}^{-1} \mathrm{VC}$ increased around $13.2 \%$ of grain $\mathrm{N}$ uptake. This means that additional $\mathrm{VC}$ application in this treatment stimulated further grain $\mathrm{N}$ uptake by $9.7 \mathrm{~kg} \mathrm{ha}^{-1}$.

\section{Phosphorus uptake of sweet corn in stover and grain}

Stover P uptake of sweet corn plants was significantly $(P<0.05)$ affected by the application of inorganic fertilizer NPK, VC and their combinations under potentially hardsetting soil as illustrated in Fig. 4. Lowest P uptake was noted in plot with no-fertilizer application. The application of full NPK significantly increased P uptake $(P<0.05)$ by $92.7 \%$ compared with no-fertilizer application. Approximately $37.9 \%$ lower P uptake was noted in sweet corn stover applied with $2 \mathrm{Mg} \mathrm{ha}^{-1} \mathrm{VC}$ in comparison with full NPK. In contrast to the applied $2 \mathrm{Mg} \mathrm{ha}^{-1} \mathrm{VC}$ stover P uptake, the application of $1 / 2 \mathrm{NPK}+2 \mathrm{Mg} \mathrm{ha}^{-1}$ VC increased by around $40.8 \%$ or $4.9 \mathrm{~kg} \mathrm{ha}^{-1}$. Comparing 
the application of $1 / 2 \mathrm{NPK}+1 \mathrm{Mg} \mathrm{ha}^{-1} \mathrm{VC}$ and full $\mathrm{NPK}+1 \mathrm{Mg} \mathrm{ha}^{-1} \mathrm{VC}$, the latter was approximately $68.7 \%$ higher than the former, which was statistically different $(P<0.05)$. Considering the $1 / 2$ NPK difference between the two treatments, $P$ uptake in stover significantly increased $(P<0.05)$ by around $9.6 \mathrm{~kg} \mathrm{ha}^{-1}$.

Grain $\mathrm{P}$ uptake was significantly affected $(P<0.05)$ by the application of inorganic fertilizer and $\mathrm{VC}$, and their combinations under potentially hardsetting soil as shown in Fig. 4. The application of full NPK increased grain P uptake by approximately $4.6 \mathrm{~kg} \mathrm{ha}^{-1}$ compared with no-fertilizer application. The additional $1 \mathrm{Mg} \mathrm{ha}^{-1}$ $\mathrm{VC}$ from treatment $1 / 2 \mathrm{NPK}+2 \mathrm{Mg} \mathrm{ha}^{-1} \mathrm{VC}$ increased grain $\mathrm{P}$ uptake by around $8.5 \%$ compared with $1 / 2$ $\mathrm{NPK}+1 \mathrm{Mg} \mathrm{ha}^{-1} \mathrm{VC}$. The application of $2 \mathrm{Mg} \mathrm{ha}^{-1} \mathrm{VC}$ resulted to a significantly $(P<0.05)$ lower grain $P$ uptake of around $3.6 \mathrm{~kg} \mathrm{ha}^{-1}$ against full NPK application. Highest grain P uptake was observed in full NPK $+1 \mathrm{Mg} \mathrm{ha}^{-1}$ $\mathrm{VC}$ application, wherein additional $1 \mathrm{Mg} \mathrm{ha}^{-1} \mathrm{VC}$ in this treatment increased grain $\mathrm{P}$ uptake by approximately 37.5\% compared with full NPK application.

\section{Potassium uptake of sweet corn in stover and grain}

As illustrated in Fig. 4, significant effects were noted on the $\mathrm{K}$ uptake of sweet corn in stover and grain. No fertilizer application showed the minimum uptake amount of $80.4 \mathrm{~kg} \mathrm{ha}^{-1}$. This uptake increased by $20.2 \%$ when treated with $2 \mathrm{Mg} \mathrm{ha}^{-1} \mathrm{VC}$, however not statistically significant $(P<0.05)$. An increase of approximately $11.8 \%$ stover $\mathrm{K}$ uptake was observed in treatment $1 / 2 \mathrm{NPK}+2 \mathrm{Mg} \mathrm{ha}^{-1} \mathrm{VC}$ against the application of $1 / 2 \mathrm{NPK}+1 \mathrm{Mg} \mathrm{ha}^{-1} \mathrm{VC}$. The additional $1 \mathrm{Mg} \mathrm{ha}^{-1}$ $\mathrm{VC}$ applied increased $\mathrm{K}$ uptake by $11.6 \mathrm{~kg} \mathrm{ha}^{-1}$; however, difference was not statistically significant $(P<0.05)$. The application of full NPK increased by approximately $70.5 \%$ compared with no-fertilizer application. In comparison with full NPK, the additional $1 \mathrm{Mg} \mathrm{ha}^{-1} \mathrm{VC}$ from treatment full NPK $+1 \mathrm{Mg} \mathrm{ha}^{-1} \mathrm{VC}$ had increased stover $\mathrm{K}$ uptake by approximately $12.7 \%$.

The application of $2 \mathrm{Mg} \mathrm{ha}^{-1} \mathrm{VC}$ showed no significant $(P>0.05)$ difference with no-fertilizer application on grain $\mathrm{K}$ uptake of sweet corn as displayed in Fig. 4. The application of full NPK in comparison with $1 / 2$ NPK $+1 \mathrm{Mg} \mathrm{ha}^{-1} \mathrm{VC}$ significantly $(P<0.05)$ increased grain $\mathrm{K}$ uptake by approximately $64.1 \%$. Application of full NPK $+1 \mathrm{Mg} \mathrm{ha}^{-1} \mathrm{VC}$ increased significantly $(P<0.05)$ by around $10.9 \mathrm{~kg} \mathrm{ha}^{-1}$ of grain $\mathrm{K}$ uptake compared with $1 / 2 \mathrm{NPK}+2 \mathrm{Mg} \mathrm{ha}^{-1} \mathrm{VC}$.

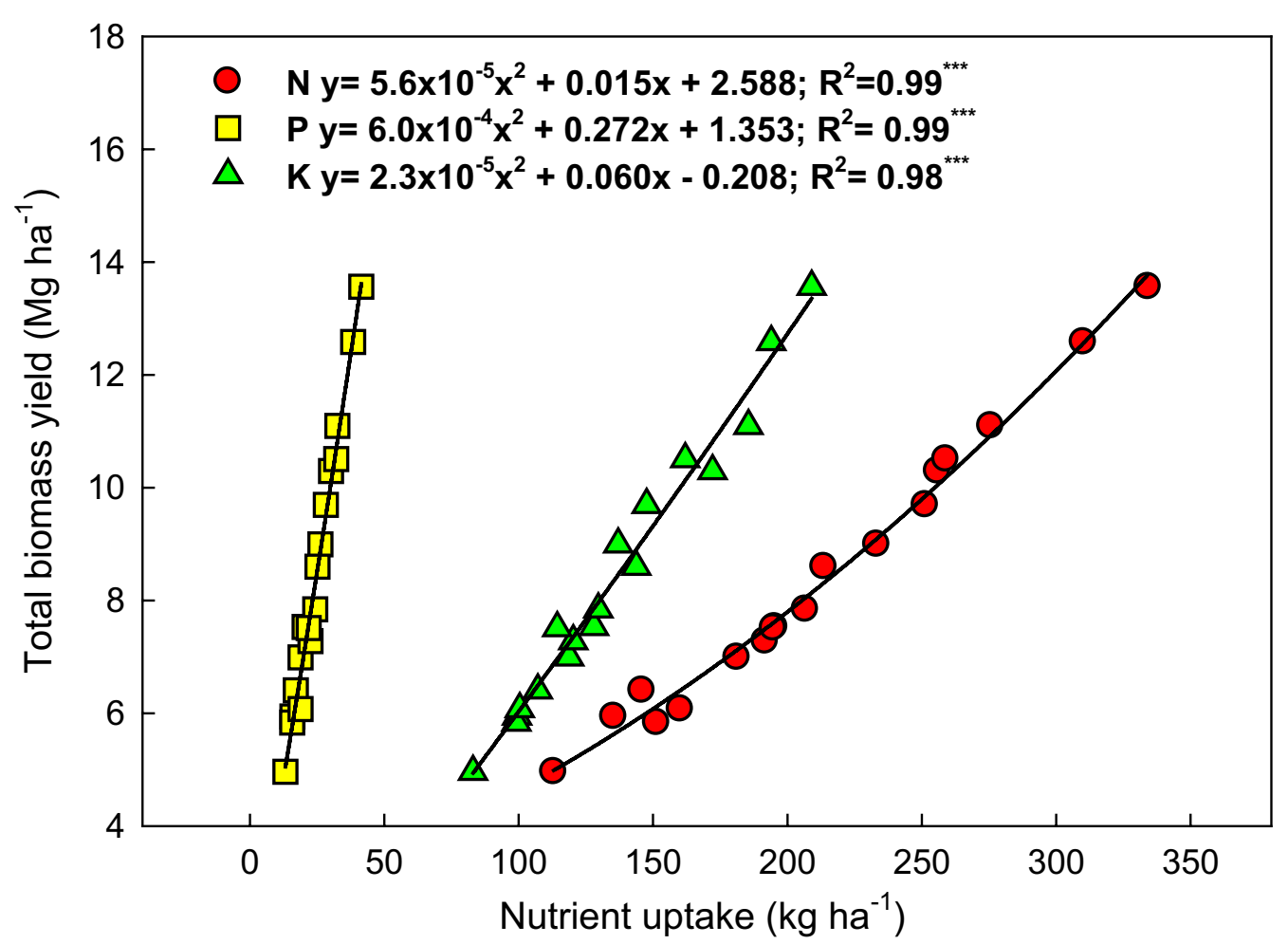

Fig. 5 Relationship of nutrient uptake ( $N, P$, and $K$ ) and total biomass yield (stover + grain) of sweet corn as influenced by different fertilization 


\section{Relationship between nutrient uptake and total biomass yield}

The total biomass (stover + grain) yield $(y)$ corresponded significantly $(P<0.001)$ with nutrient $(\mathrm{N}, \mathrm{P}$, and $\mathrm{K})$ uptake $(x)$ and revealed a quadratic relationship as shown in Fig. 5. Irrespective with treatments, a quadratic equation of $y=5.6 \times 10^{-5} x^{2}+0.015 x+2.588, R^{2}=0.99^{* * * *}, y=6.0 \times$ $10^{-4} x^{2}+0.272 x+1.353, R^{2}=0.99^{* * * a}$ and $y=2.9 \times 10^{-5} x^{2}$ $+0.060 x-0.208, \mathrm{R}^{2}=0.98^{* * * *}$ was derived from the $\mathrm{N}, \mathrm{P}$, and $\mathrm{K}$ uptakes, respectively, and total biomass yield. This equation could be interpreted that changes in nutrient uptake could result to corresponding quadratic changes in total biomass yield under potentially hardsetting soil. Approximately $98-99 \%$ of the variation in total biomass could be explained by nutrient uptake.

\section{Nutrient use efficiency (NUE)}

Across all treatments, internal efficiency of $\mathrm{N}\left(\mathrm{IE}_{\mathrm{N}}\right)$ and $\mathrm{P}\left(\mathrm{IE}_{\mathrm{P}}\right)$ varies considerably $(P<0.001)$ from 7.16 to $9.33 \mathrm{~kg} \mathrm{~kg}^{-1}$ and 60.90 to $79.17 \mathrm{~kg} \mathrm{~kg}^{-1}$, respectively (Table 1). This indicates that per $\mathrm{kg}$ of $\mathrm{N}$ and $\mathrm{P}$ absorbed by sweet corn plant under full NPK fertilization could generate $9-79 \mathrm{~kg}$ of grains. On the other note, reciprocal internal efficiency of $N\left(R_{N}\right)$ and $P\left(R_{P}\right)$ was highly influenced by fertilization $(P<0.001)$ under hardsetting soil (Table 1), highest was noted from plants treated with $1 / 2 \mathrm{NPK}+1 \mathrm{Mg} \mathrm{ha}^{-1} \mathrm{VC}$ with $139.65 \mathrm{~kg}$ and $16.42 \mathrm{~kg}$, respectively, which means that $139.65 \mathrm{~kg}$ of $\mathrm{N}$ and $16.42 \mathrm{~kg}$ of $\mathrm{P}$ must be supplied in order to produce $1000 \mathrm{~kg}$ grain yield. More so, nutrient harvest index (HI) refers to the proportion between nutrient accumulated in grain to nutrient accumulated in grain plus straw, and in this study $\mathrm{N}\left(\mathrm{HI}_{\mathrm{N}}\right)$ and $\mathrm{P}\left(\mathrm{HI}_{\mathrm{P}}\right)$. In our investigation, fertilizer application significantly influenced $(P<0.001) \mathrm{HI}_{\mathrm{N}}$ and $\mathrm{HI}_{\mathrm{P}}$ of sweet corn grown in a potentially hardsetting soil. Across treatments, full NPK application had the highest $\mathrm{HI}_{\mathrm{N}}$ indicating highest $\mathrm{N}$ partitioning to grains while applied full NPK $+1 \mathrm{Mg} \mathrm{ha}^{-1} \mathrm{VC}$ had the highest $\mathrm{HI}_{\mathrm{P}}$. Another parameter to measure the efficiency of fertilization is partial factor productivity (PFP), wherein significant influence $(P<0.001)$ was noted by fertilization (Table 1). Full NPK application had $26-76 \%$ and $37-108 \%$ higher $\mathrm{PFP}_{\mathrm{N}}$ and $\mathrm{PFP}_{\mathrm{P}}$ across treatments, respectively. In this study, the application of $1 / 2 \mathrm{NPK}+2 \mathrm{Mg} \mathrm{ha}^{-1} \mathrm{VC}$ had the lowest $\mathrm{PFP}_{\mathrm{N}}$ value which further suggests that supply is going to a yield plateau level, hence, the grain produced from the applied $\mathrm{N}$ could reduce. Agronomic efficiency (AE) is another parameter to measure NUE. In this investigation, AE was significantly influenced by fertilization $(P<0.001)$. The application of full NPK manifested the highest $\mathrm{AE}_{\mathrm{N}}$ and $\mathrm{AN}_{\mathrm{P}}$ of $17.47 \mathrm{~kg} \mathrm{~kg}^{-1}$ and $56.02 \mathrm{~kg} \mathrm{~kg}^{-1}$, respectively, which corresponds to $16-364 \%$ and 25-425\% higher across treatments. Another indicator of nutrient use efficiency is physiological efficiency (PE) which reveals the degree by which applied nutrients are physiologically assimilated by fertilized crops. In this study, physiological efficiency of $\mathrm{N}\left(\mathrm{PE}_{\mathrm{N}}\right)$ and $\mathrm{P}$ $\left(\mathrm{PE}_{\mathrm{P}}\right)$ was non-comparable $(P<0.001)$ among treatments (Table 1). Highest $P E_{N}$ and $P E_{P}$ values were observed from the application of $2 \mathrm{Mg} \mathrm{ha}^{-1} \mathrm{VC}$ of $12.45 \mathrm{~kg} \mathrm{~kg}^{-1}$

Table $1 \mathrm{~N}$ and $\mathrm{P}$ harvest index $(\mathrm{HI})\left(\mathrm{kg} \mathrm{kg}^{-1}\right)$, internal efficiency (IE) $\left(\mathrm{kg} \mathrm{kg}^{-1}\right)$, reciprocal internal efficiency (RIE) ( $\left.\mathrm{kg} \mathrm{t} \mathrm{t}^{-1}\right)$, agronomic use efficiency (AE) $\left(\mathrm{kg} \mathrm{kg}^{-1}\right)$, physiological efficiency (PE) $\left(\mathrm{kg} \mathrm{kg}^{-1}\right)$, partial factor productivity (PFP) $\left(\mathrm{kg} \mathrm{kg}^{-1}\right)$, and recovery efficiency (RE) (\%) of sweet corn under different fertilization

\begin{tabular}{|c|c|c|c|c|c|c|}
\hline Parameter & Full NPK & $2 \mathrm{Mg} \mathrm{ha}^{-1} \mathrm{VC}$ & $1 / 2 \mathrm{NPK}+1 \mathrm{Mg} \mathrm{ha}^{-1} \mathrm{VC}$ & $1 / 2 \mathrm{NPK}+2 \mathrm{Mg} \mathrm{ha}^{-1} \mathrm{VC}$ & Full NPK + $1 \mathrm{Mg} \mathrm{ha}^{-1} \mathrm{VC}$ & $F$ test \\
\hline $\mathrm{IE}_{\mathrm{N}}$ & $9.33^{\mathrm{a}, 1}$ & $8.15^{c}$ & $7.16^{\mathrm{e}}$ & $7.58^{d}$ & $8.55^{b}$ & $* * * 2$ \\
\hline $\mathrm{RIE}_{\mathrm{N}}$ & $107.14^{e}$ & $122.63^{c}$ & $139.65^{a}$ & $131.88^{b}$ & $116.94^{d}$ & $* * *$ \\
\hline$H \mathrm{I}_{\mathrm{N}}$ & $0.30^{\mathrm{a}}$ & $0.25^{c}$ & $0.26^{c}$ & $0.24^{d}$ & $0.28^{b}$ & $* * *$ \\
\hline $\mathrm{PFP}_{\mathrm{N}}$ & $33.12^{a}$ & $25.44^{b}$ & $21.09^{c}$ & $18.78^{d}$ & $26.21^{b}$ & $* * *$ \\
\hline$A E_{N}$ & $17.47^{\mathrm{a}}$ & $6.02^{c}$ & $3.76^{\mathrm{d}}$ & $6.80^{c}$ & $15.06^{b}$ & $* * *$ \\
\hline$P E_{N}$ & $10.52^{a b}$ & $12.45^{\mathrm{a}}$ & $3.83^{d}$ & $6.47^{c}$ & $8.73 b^{c}$ & $* * *$ \\
\hline $\mathrm{RE}_{\mathrm{N}}$ & $167^{\mathrm{a}}$ & $79^{c}$ & $87^{c}$ & $104^{b}$ & $173^{\mathrm{a}}$ & $* * *$ \\
\hline $\mathrm{IE}_{\mathrm{p}}$ & $79.17^{a}$ & $78.27^{a}$ & $60.90^{c}$ & $67.51^{b}$ & $68.98^{b}$ & $* * *$ \\
\hline $\mathrm{RIE}_{\mathrm{p}}$ & $12.63^{c}$ & $12.78^{c}$ & $16.42^{a}$ & $14.81^{b}$ & $14.50^{b}$ & $* * *$ \\
\hline $\mathrm{HI}_{\mathrm{p}}$ & $0.34^{d}$ & $0.35^{c}$ & $0.36^{b}$ & $0.34^{d}$ & $0.37^{a}$ & $* * *$ \\
\hline$P F P_{P}$ & $106.19^{a}$ & $62.92^{c}$ & $59.74^{c}$ & $50.92^{d}$ & $77.47^{b}$ & $* * *$ \\
\hline$A E_{p}$ & $56.02^{a}$ & $14.89^{c d}$ & $10.66^{d}$ & $18.43^{c}$ & $44.51^{b}$ & $* * *$ \\
\hline$P E_{p}$ & $88.48^{a}$ & $190.13^{a}$ & $32.24^{a}$ & $61.35^{a}$ & $67.36^{\mathrm{a}}$ & ns \\
\hline$R E_{p}$ & $64^{a}$ & $13^{c}$ & $29^{b}$ & $30^{b}$ & $66^{a}$ & $* * *$ \\
\hline
\end{tabular}

\footnotetext{
${ }^{1}$ Values in the same row within the same parameter followed by different letters are significantly different at $P<0.05$ according to Tukey's HSD test

2 ns denotes not significant, while ${ }^{*},{ }^{*}$, and ${ }^{* * *}$ denote significant difference at $0.05,0.01$, and 0.001 levels of significance
} 
and $190.13 \mathrm{~kg} \mathrm{~kg}^{-1}$, on the contrary, lowest was observed from the application of $1 / 2 \mathrm{NPK}+1 \mathrm{Mg} \mathrm{ha}^{-1} \mathrm{VC}$. Another way to characterize the fertilizer applications efficiency is via applied nutrient recovery efficiency (RE). In this study RE was significantly influenced by fertilization $(P<0.001)$, hence, $\mathrm{RE}_{\mathrm{N}}$ and $R E_{\mathrm{P}}$ in applied full NPK $+1 \mathrm{Mg} \mathrm{ha}^{-1} \mathrm{VC}$ was 3.6 to $119 \%$ and 3.1 to $407.7 \%$ higher among treatments, respectively.

\section{Soil strength development}

Significant results were noted from the laboratory experiment aimed to determine soil strength development in non-puddled and puddled (stirred) conditions of soil in the experimental area (Fig. 6). Puddling was employed to simulate the cultivation of soil at saturated condition. Under normal condition (non-puddled), soil strength values from day 1 to day 10 were low $\left(<10 \mathrm{~kg} \mathrm{~cm}^{-2}\right)$, indicating that the soil of the experimental area is nonhardsetting. However, under puddled condition soil strength values at day 5 and onwards were significantly high very high $(P<0.001)$. The puddled/non-puddled ratios (soil strength at puddled condition divided by the soil strength values at non-puddled condition) from day 5 onward were generally greater than 10 , implying that the soil of the experimental area is potentially hardsetting. It was noted in day 5 of puddled soils that it had increased in strength of about $43.84 \mathrm{~kg} \mathrm{~cm}^{-2}$ compared to nonpuddled of only $3.99 \mathrm{~kg} \mathrm{~cm}^{-2}$. As day progresses, puddled soil keeps on increasing in strength.

\section{Discussion}

Over all, under potentially hardsetting soil with varying effects of fertilization level, sweet corn responded differently in total biomass accumulation and nutrient uptake. The varying level in nutrient uptake of sweet corn demonstrated that nutrients were accessible to plants amidst unfavorable soil physical condition. Highest biomass accumulation was observed in the application of full $\mathrm{NPK}+1 \mathrm{Mg} \mathrm{ha}^{-1} \mathrm{VC}$ while lowest was in no-fertilizer application plot (Fig. 3). This conforms to the study of Liang et al. (2012) who pointed that continuous organic and inorganic fertilizer application under wheat and maize production system would significantly increase yield in comparison with unfertilized control plots. In full NPK-treated plot, stover biomass increased by $64 \%$ over no-fertilizer treatment. This was due to the essential macronutrients supplied by inorganic fertilizer particularly $\mathrm{N}$ and $\mathrm{P}$ as well as from the inherent supply of mineralized nutrients in the soil (Masclaux-Daubresse et al. 2010; Seleiman and Kheir 2018). Inorganic fertilizers are composed of readily available nutrients that are rapidly supplied to crops in a short period of time right

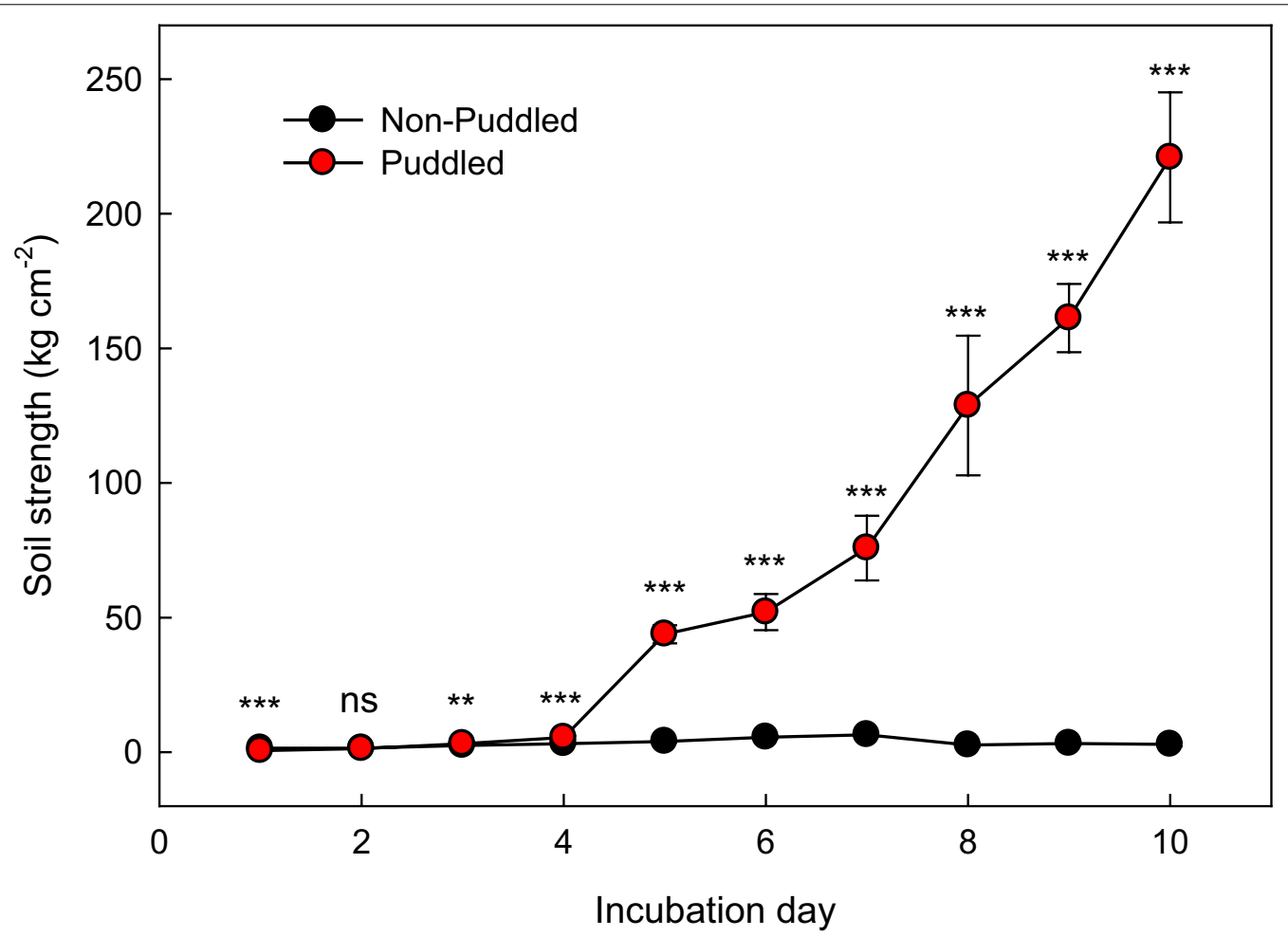

Fig. 6 Soil strength development of the experimental area. Vertical bars indicate standard deviations $(n=4)$ 
after application (Sarker et al. 2017). These essential nutrients are needed by plants for physiological metabolism and nutrition. However, stover biomass accumulation in no-fertilizer application treatment was observed not significantly different with $2 \mathrm{Mg} \mathrm{ha}^{-1} \mathrm{VC}$ and $1 / 2$ NPK $+1 \mathrm{Mg} \mathrm{ha}^{-1} \mathrm{VC}(P>0.05)$. This could be due to the low mineralized nutrients supplied by these fertilizer combinations compared with full NPK $+1 \mathrm{Mg} \mathrm{ha}^{-1} \mathrm{VC}$. The higher macronutrients present in inorganic fertilizers are already mineralized and hence readily available for plant acquisition. In addition, since $\mathrm{VC}$ was applied together with full NPK, it could be that the $\mathrm{C} / \mathrm{N}$ ratio of compost went narrower due to the presence of high $\mathrm{N}$ from inorganic fertilizer which then favors mineralization of organic N in VC (Seleiman et al. 2013). The microorganisms facilitate enzymatic biochemical mineralization process of nutrients present in organic fertilizers like VC, particularly N (Kader et al. 2017). The mineralized nutrients are then released to exchange sites and held available for plant absorption (Muktamar et al. 2017). Organic amendments like VC contain low amount of nutrients, and most nutrient elements are in organic form. In this study, the application of $2 \mathrm{Mg} \mathrm{ha}^{-1} \mathrm{VC}$ supplied approximately $56.4 \mathrm{~kg}$ of N compared to $70 \mathrm{~kg} \mathrm{~N}$ from full NPK; hence, full NPK application resulted to $43 \%$ and $62 \%$ higher stover and grain biomass, respectively. This implies that inorganic fertilizer application under potentially hardsetting soil is highly efficient in increasing stover and grain biomass due to the mineralized nutrient elements available for crops leading them to accumulate higher biomass level (Baghdadi et al. 2018; Hassan et al. 2020). However, combined application of inorganic fertilizer and organic amendment manifested significantly higher stover and grain biomass across treatments (Fig. 3). The application of full NPK $+1 \mathrm{Mg} \mathrm{ha}^{-1}$ VC increased by approximately $26-106 \%$ and $11-135 \%$ in stover and grain biomass across treatments, respectively. The right combination of inorganic fertilizer and compost offers optimum nutrition in growing crops, starting from vegetative stage toward yield productivity on a sustainable basis (Mahmood et al. 2017). In grain biomass, application of full NPK $+1 \mathrm{Mg} \mathrm{ha}^{-1} \mathrm{VC}$ was significantly highest among treatments except with full NPK application. The presence of high and available nutrients from full NPK fertilization of both treatments might be an effective fertilization scheme to increase grain biomass productivity of sweet corn in a potentially hardsetting soil condition.

The N, P, and K uptake of sweet corn showed a similar trend. Across treatments, the application of full $\mathrm{NPK}+1 \mathrm{Mg} \mathrm{ha}^{-1} \mathrm{VC}$ had been consistently the highest in nutrient uptake among treatments. This coincides to the previous reports that incorporation of combined organic amendments and inorganic fertilizer can significantly increase grain N uptake (Puli et al. 2017; Canatoy 2018a). Increase in $\mathrm{N}$ uptake could be attributed to the gradual but continuous supply of available nutrients (i.e., $\mathrm{NH}_{4}{ }^{+}, \mathrm{NO}_{3}{ }^{-}$) from organic amendment, along with reduction in $\mathrm{N}$ losses through volatilization, denitrification and leaching. This facilitates favorable synchrony between crop $\mathrm{N}$ demands and supply from the soil (Haile et al. 2012).

Conversely, plant soluble $\mathrm{P}$ is governed by numerous factors that are related to existing soil properties like $\mathrm{pH}$, precipitation with $\mathrm{Ca}, \mathrm{Al}$, and $\mathrm{Fe}$, and sorption (Malik et al. 2012; Khan and Joergensen 2009). Further, Malik et al. (2012) elucidated that approximately 80-90\% of applied mineral P becomes plant unavailable due to opposing soil conditions. Feil et al. (1992) and Holou et al. (2011) expounded that additional N application could consistently increase P uptake under a continuous corn cultivation system. The applied $\mathrm{N}$ fertilizer could proliferate root branching in surface portion where closer to higher P concentration (Postma et al. 2014). Numerous studies described that around fivefold-tenfold increase in P uptake could be attributed to an increase in root area alone (Schenk and Barber 1979; Gahoonia and Nielsen 1997; Machando and Furlani 2004). This supports the previous reports that the nutrient concentration in plant tissue is directly proportional to the amount of available nutrients present in the soil (Mengel and Kirkby 1987; Puli et al. 2017). Increased root growth could enhance the root surface area whereby increasing the $\mathrm{P}$ acquisition of growing crop (Tilahun-Tadesse et al. 2013). Moreover, inherent soil chemical characteristics as well as P fertilizer source are determining factors for phosphorus availability (Havlin 1999; Girma et al. 2017). Thus, the application of full NPK $+1 \mathrm{Mg} \mathrm{ha}^{-1}$ VC supplied the optimum $\mathrm{P}$ level as manifested in the stover of sweet corn plants.

The full development of root system in a mineral-fertilized soil could enhance the acquisition of $\mathrm{K}$ as roots ramify in soil. Reports have said that around $86 \%$ of $\mathrm{K}$ is supplied to plant roots via diffusion transport mechanism from soil solution (Barber 1974). In comparison with full NPK, the additional $1 \mathrm{Mg}$ VC of treatment full $\mathrm{NPK}+1 \mathrm{Mg} \mathrm{ha}^{-1} \mathrm{VC}$ had increased stover K uptake by approximately $12.7 \%$. The additional nutrients supplied by $\mathrm{VC}$ enhanced further the acquisition of $\mathrm{K}$ in the soil. Moreover, it was earlier reported that with VC application, $\mathrm{K}$ concentration in leaf increases significantly (Hosseinzadeh and Ahmadpour 2018). Meanwhile, $\mathrm{VC}$ application can also improve the physicochemical properties of soil including soil organic $\mathrm{C}, \mathrm{pH}, \mathrm{EC}$ (electrical conductivity), bulk density, and total porosity (Azarmi et al. 2008; Canatoy 2018b). Hence, increase 
$\mathrm{K}$ and $\mathrm{Ca}$ acquisition via root absorption (Hosseinzadeh and Ahmadpour 2018). Wang et al. (2007) reported that under reduced tillage maximum $\mathrm{K}$ assimilation was observed at NP fertilization with $100 \mathrm{~kg} \mathrm{ha}^{-1}$ rate. Hence, when combining inorganic and organic fertilizer in amending soil fertility, higher inorganic portion rather than organic would lead to higher grain nutrient uptake in potentially hardsetting soil under no tillage.

The pattern in nutrient uptake among treatments resembles with their respective biomass accumulation both in stover and grain biomass. In this study, resemblance was figured out to have quadratic relationship. Irrespective with treatments, a quadratic equation was derived from the $\mathrm{N}, \mathrm{P}$, and $\mathrm{K}$ uptakes, respectively, and total biomass yield. This equation implies that changes in nutrient uptake could result to corresponding quadratic changes in total biomass yield under potentially hardsetting soil. In addition, since the relationship was in parabolic model, this means that increase in nutrient uptake has limit for an increase in total biomass yield (Fageria and Baligar 2001). This strong parabolic relationship further revealed that approximately $98-99 \%$ of the variation in total biomass could be explained by nutrient uptake.

The concept of nutrient use efficiency (NUE) has been accepted and used as means to evaluate the production systems of different crops. In addition, NUE can be markedly influenced by fertilization schemes and level along with soil and plant-water relationships (Singh et al. 2018). NUE serves as an indication for potential losses of nutrients from the cropping system toward the environment as farmland managers aim to supply the continuous demand for basic needs like food, fuel and fiber. Lower NUE in a given agroecosystem might be alarming as this may be perceived as potentially detrimental to the environment through ground water contamination and toxicity while those that have high NUE may indicate lesser environmental threat (Thompson 2012).

Among the essential elements for crop nutrition, $\mathrm{N}$ normally restricts crop productivity level (Mosier et al. 2002). It executes critical importance in any crop production system due to its huge role in all of plants biochemical activities and its substantial losses is ascribed with the interaction in soil-plant systems (Ladha and Reddy 2003). Next to N is P as the second element that is highly demanded by corn due to its direct influence on the development and grain productivity (Dhillon et al. 2017). P is another nutrient element considered to be limited in many agroecosystems (Guignard et al. 2017; Khan et al. 2018). Approximately $67 \%$ of global agricultural land is estimated to be P deficient; thus, $\mathrm{P}$ use efficiency in global cereal production is low ranging within 15 to 30\% (Dhillon et al. 2017). Moreover, in tropical regions, $\mathrm{P}$ can react with aluminum and iron, which only becomes available when $\mathrm{pH}$ is corrected (Penn and Camberato 2019).

$\mathrm{HI}_{\mathrm{N}}$ is considered as an imperative index in measuring crop yields because it positively correlates with grain yield (Fageria 2014). On the other side, in relation to $\mathrm{N}$ or $\mathrm{P}$ rate used, PFP is a comprehensive means to measure the grain production efficiency. In $\mathrm{PFP}_{\mathrm{N}}$, for example, it should be noted that low-level fertilization could generate considerable $\mathrm{PFP}_{\mathrm{N}}$ values due to crops' response to existing climatic condition and low supply of native $\mathrm{N}$ (Fischer et al. 2014). AE is a measurement that shows the direct production influence of fertilizer being applied and relates accordingly to economic return (Cassman et al. 1996). Moreover, this measures the direct influence of $\mathrm{N}$ or $\mathrm{P}$ fertilization after subtracting the contribution of $\mathrm{N}$ or $\mathrm{P}$ supplied by soil. In this investigation, $\mathrm{AE}$ was significantly influenced by varying fertilization treatments and full NPK treatment manifested the highest AE $(P<0.001)$. Underestimation of the natural supply of $\mathrm{N}$ or $\mathrm{P}$ would cause over fertilization and decline AE (Olk et al. 1998). Another way to characterize fertilizer applications efficiency is via applied nutrient recovery efficiency (RE) being defined as the fraction of nutrient assimilated by crops from the total nutrient applied in cultivated lands, not including the loss of nutrient and the remaining amount left in the soil (Zhu and Chen 2002). RE has been extensively used in many farming lands as an index in assessing the nutrient use efficiency (Chen et al. 2015; Backer et al. 2017). In our investigation, significant differences were observed among treatments $(P<0.05)$, and highest RE was observed in the application of full $\mathrm{NPK}+1 \mathrm{Mg} \mathrm{ha}^{-1} \mathrm{VC}$.

Soil degradation is a gradual process that leads to the formation of problem soils. It is a phenomenon wherein soil lowers and loses its prime functions to support and nourish crops and provide habitat for soil flora and fauna (Menta 2012). This becomes a major concern of the global scientific community in the past recent decades. Thus, it poses a serious threat toward global agricultural food production and terrestrial environment. Soil resources in around 2 billion hectares globally have deteriorated, and this area keeps increasing due to widespread mismanagement (Naseer and Pandey 2018). Physical and chemical deterioration and soil erosion are among soil degradation types that have been identified to be commonly present in all parts of the world. Soil degradation may be a natural phenomenon; however, this could be enhanced or inhibited by diverse anthropogenic ways (Emadodin and Bork 2012). Overgrazing, continuous cropping, chemical fertilization, deforestation, and excessive tillage are few of the inappropriate practices employed in the field during food production process that has significant drawbacks in the long run. Degraded soil directly affects food supply 
and estimated around 11.9 to $13.4 \%$ of agricultural food supply which has been gone in the past decades (Jie et al. 2002).

Soil hardsetting behavior is generally linked with soil degradation processes including soil acidification, compaction, erosion and crusting (Mullins 1997). Soils of these kind are most of the time frustrating because of its very low productivity and overwhelming cost/benefit ratio. Several constraints in agricultural production are related to hardsetting soils, one is limited time for soil tillage and inadequate root development due to the presence of physical restrictions (Mullins et al. 1987, 1990). This affects the nutrient acquisition capacity, nutrient, and water uptake of crops as compaction brought by hardsetting could decrease root length and impermeability (Nosalewicz and Lipiec 2014). In our investigation, the cultivated sweet corn in potentially hardsetting soil manifested significant response to varying fertilization combination under no-tillage system. It demonstrated that under potentially hardsetting soil, the application of inorganic fertilizer manifested significant nutrient uptake and total biomass; however, this current soil situation may worsen if improperly managed. The beginning of hardsetting behavior of soil is linked to organic matter loss due to conventional tillage, surface runoff, and erosion. However, it is not the literal loss of organic components of soil, but the removal of more labile organic fractions duly considered as binding agents among soil particles (Daniells 2012). The soil organic carbon component of soil organic matter can be critically influenced the stability of aggregates as well as soil structure. Hence, the addition of organic amendment could be an option to facilitate the binding of soil particles by its labile fraction and build up soil structure (Alagöz and Yilmaz 2009). Moreover, organic amendment addition could gradually replenish plant-removed nutrients and improve important soil properties (Palm et al. 2001). Since potentially hardsetting soil may become full-blown hardsetting soil under degraded soils if continually mismanaged, periodic addition of organic matter as part of the production process in agricultural fields may be considered.

\section{Conclusion}

The application of full NPK $+1 \mathrm{Mg} \mathrm{ha}^{-1} \mathrm{VC}$ increased stover and grain yield by $26-106 \%$ and $11-135 \%$, respectively. Approximately $64 \%$ and $112 \%$ of sweet corn stover and grain yield increased when treated with full NPK. Highest N, P, and K uptakes in stover were observed in plot with full NPK $+1 \mathrm{Mg} \mathrm{ha}^{-1} \mathrm{VC}$, which was $24 \%, 22 \%$, and $13 \%$ higher than full NPK, respectively, which was due to the additional nutrients supplied by $1 \mathrm{Mg} \mathrm{ha}^{-1}$ VC. Grain N, P, and K uptake in control might increase by approximately $102 \%, 86 \%$, and $86 \%$, respectively, when treated with full NPK. However, higher increase of about $128 \%, 156 \%$, and $110 \%$, respectively, when treated with full NPK $+1 \mathrm{Mg} \mathrm{ha}^{-1} \mathrm{VC}$. The applied full $\mathrm{NPK}+1 \mathrm{Mg} \mathrm{ha}^{-1} \mathrm{VC}$ manifested comparable differences in stover and grain biomass yields and nutrient uptake with full NPK application in a potentially hardsetting soil. A highly significant quadratic relationship $(P<0.001)$ was revealed between total biomass yield and nutrient uptake of sweet corn, which means that $98-99 \%$ of the variation in total biomass could be elucidated by the nutrient uptake. Indicating suitability of nutrient uptake function could be used as an estimate in the progression of total biomass accumulation. The application of full NPK showed statistically significant $(P<0.001)$ nitrogen and phosphorus use efficiency across treatments. The soil in the experimental area had potential hardsetting characteristics due to its rapid soil strength development of at least 4 days from wetting. This implies that proper soil management must be implemented like reduced tillage and organic matter application to facilitate structure formation via less disturbance due to tillage and binding of soil particles by labile organic fraction in organic matter. Therefore, application of organic matter as soil amendment in combination with inorganic fertilizer could be a sustainable production strategy under sweet corn production system in potentially hardsetting soil under no tillage through enhanced nutrient uptake and biomass accumulation.

\section{Abbreviations \\ SOC: Soil organic carbon; N: Nitrogen; P: Phosphorus; K: Potassium; C: Carbon; SOM: Soil organic matter; HI: Nutrient harvest index; IE: Internal nutrient effi- ciency; RIE: Reciprocal internal nutrient efficiency; AE: Agronomic nutrient use efficiency; PFP: Partial nutrient factor productivity; PE: Physiological nutrient efficiency; RE: Recover efficiency of applied nutrient; STAR: Statistical Tool for Agricultural Research; Mg: Mega gram; kg: Kilogram; ha: Hectare; mm: Mil- limeter; $\mathrm{cmol}_{\text {: }}$ Centimole; g: Gram; cm: Centimeter; mg: Milligram; m: Meter; ANOVA: Analysis of variance; HSD: Honestly significant difference.}

\section{Acknowledgements}

The authors are thankful to DOST PAGASA for providing the climatological data reported in this research article. In addition, the authors are grateful to Central Mindanao University administration for the support in the conduct of the study.

\section{Authors' contributions}

RCC conceptualized, conducted, analyzed, and interpreted the data regarding total biomass and nutrient uptake and wrote the draft of the manuscript. NPD conceptualized, edited, and interpreted the data on result of soil strength development. All authors read and approved the final manuscript.

\section{Funding}

Not applicable.

\section{Availability of data and materials}

The datasets generated during and/or analyzed during the current study could be personally asked from the corresponding author. Anyone who wishes to have a copy of it may be given for research purposes provided proper citation. You may send your request to the corresponding author. 


\section{Declarations}

Ethics approval and consent to participate Not applicable.

\section{Consent for publication}

Not applicable.

\section{Competing interests}

The authors declare that they have no competing interests.

\section{Author details}

${ }^{1}$ Department of Soil Science, College of Agriculture, Central Mindanao University, Maramag, Philippines. ${ }^{2}$ Division of Applied Life Science, Gyeongsang National University, Jinju 660-701, South Korea.

Received: 28 January 2021 Accepted: 8 March 2021

\section{Published online: 17 March 2021}

\section{References}

Alagöz Z, Yilmaz E (2009) Effects of different sources of organic matter on soil aggregate formation and stability: a laboratory study on a Lithic Rhodoxeralf from Turkey. Soil Tillage Res 103:419-424

Azarmi R, Giglou MT, Taleshmikail RD (2008) Influence of vermicompost on soil chemical and physical properties in tomato (Lycopersicum esculentum) field. Afr J Biotechnol 7(14):2397-2401

Backer RGM, Saeed W, Seguin P, Smith DL (2017) Root traits and nitrogen fertilizer recovery efficiency of corn grown in biochar-amended soil under greenhouse conditions. Plant Soil 415:1-13

Baghdadi A, Halim RA, Ghasemzadeh A, Ramlan MF, Sakimin SZ (2018) Impact of organic and inorganic fertilizers on the yield and quality of silage corn intercropped with soybean. PeerJ 6:e5280

Barber SA (1974) Influence of the plant root on ion movement in soil. In: Carson EW (ed) The plant root and its environment. University Press of Virginia, Charlottesville, pp 525-564

Biddle DL (1997) A compilation of selected methods for soil and plant chemical analysis. Department of Agriculture, University of Queensland, Australia, St Lucia

Bodirsky BL, Rolinski S, Biewald A, Weindl I, Popp A, Lotze-Campen H (2015) Global Food Demand Scenarios for the 21st Century. PLoS ONE 10(11):e0139201

Canatoy RC (2018a) Effects of vermicompost on the growth and yield of sweet corn in Bukidnon, Philippines. Asian J Soil Sci Plant Nutr 3(2):1-8

Canatoy RC (2018b) Effects of fertilization on the growth and yield of sweet corn under no tillage in Bukidnon, Philippines. Int J Sci Res Publ 8(7):443-450

Cassman KG, Gines GC, Dizon MA, Samson MI, Alcantara JM (1996) Nitrogenuse efficiency in tropical lowland rice systems: contributions from indigenous and applied nitrogen. Fields Crops Res 47:1-12

Che S, Zhao B, Li Y, Yuan L, Li W, Lin Z, Hu S, Shen B (2015) Review grain yield and nitrogen use efficiency in rice production regions in China. J Integr Agr 14(12):2456-2466

Chen G, Chen Y, Zhao GH, Cheng WD, Guo SW, Zhang HL, Shi WM (2015) Do high nitrogen use efficiency rice cultivars reduce nitrogen losses from paddy fields. Agri Ecosys Environ 209:26-33

Daniells IG (2012) Hardsetting soils: a review. Soil Res 50(5):349-359

Daquiado NP (1998) Assessing the limitations on soil productivity imposed by hardsetting properties. PhD thesis, The University of Queensland, Australia.

Dhillon J, Torres G, Driver E, Figueiredo B, Raun WR (2017) World phosphorus use efficiency in cereal crops. Agron J 109:1670-1677

Diacono M, Montemurro F (2010) Long-term effects of organic amendments on soil fertility. A review. Agron Sustain Dev 30:401-422

Ding Z, Kheir AS, Ali OA, Hafez E, Elshamey EA, Zhou Z, Wang B, Lin X, Ge Y, Fahmy AE, Seleiman MF (2021) A vermicompost and deep tillage system to improve saline-sodic soil quality and wheat productivity. J Environ Manag 277:111388
Emadodin I, Bork HR (2012) Degradation of soils as a result of long-term human-induced transformation of the environment in Iran: an overview. J Land Use Sci 7(2):203-219

Fageria NK, Baligar VC (2001) Lowland rice response to nitrogen fertilization. Commun Soil Sci Plant Anal 32:1405-1429

Fageria NK (2014) Nitrogen harvest index and its association with crop yields. J Plant Nutr 37(6):795-810

Feil B, Thiraporn R, Sramp P (1992) Can maize cultivars with low mineral nutrient concentrations in the grain help to reduce the need of fertilizers in the third world countries? Plant Soil 146(1-2):295-299

Fischer RA, Byerlee D, Edmeades GO (2014) Crop yields and global food security: will yield increase continue to feed the world? Canberra: Australian Centre for International Agricultural Research. Available from http://aciar gov.au/publication/mn158. 15 May 2015

Gahoonia TS, Nielsen NE (1997) Variation in root hairs of barley cultivars doubled soil phosphorus uptake. Euphytica 98:177-182

Gaspar AP, Laboski CAM, Naeve SL, Conley SP (2018) Secondary and micronutrient uptake, partitioning, and removal across a wide range of soybean seed yield levels. Agron J 110(4):1328-13383

Geng Y, Cao G, Wang L, Wang S (2019) Effects of equal chemical fertilizer substitutions with organic manure on yield, dry matter, and nitrogen uptake of spring maize and soil nitrogen distribution. PLoS ONE 14(7):e0219512

Girma T, Beyene S, Biazin B (2017) Effect of organic and inorganic fertilizer application on soil phosphorous balance and phosphorous uptake and use efficiency of potato in Arbegona district. Southern Ethiopia J Fertil Pestic 8:185

Ghosh M, Devi A (2019) Assessment of crop growth, soil properties and crop yield in an upland acidic soil with inorganic fertilizer blended with organic amendments in summer rice cropping seasons. Int J Recycl Org Waste Agricult 8:1-9

Guignard MS, Leitch AR, Acquisti C, Eizaguirre C, Elser JJ, Hessen DO, Jeyasingh PD, Neiman M, Richardson AE, Soltis PS, Soltis DE, Stevens CJ, Trimmer M, Weider LJ, Woodward G, Leitch IJ (2017) Impacts of nitrogen and phosphorus: from genomes to natural ecosystems and agriculture. Front Ecol Evol 5:70

Haile D, Nigussie D, Ayana A (2012) Nitrogen use efficiency of bread wheat: effects of nitrogen rate and time of application. J Soil Sci Plant Nut 12(3):389-409

Harman RM (2016) Opportunities in sustainability: maize seeders for the developing world and alternative fertilizers in the United States. Master's Thesis. University of Tennessee.

Hassan MU, Aamer M, Chattha MU, Haiying T, Khan I, Seleiman MF, Rasheed A Nawaz M, Rehman A, Aslam MT, Afzal A, Huang G (2020) Sugarcane distillery spent wash (DSW) as a bio-nutrient supplement: a win-win option for sustainable crop production. Agronomy 11(1):183

Havlin JL (1999) Soil fertility and fertilizer: an introduction to nutrient management. Prentice Hall, Upper Saddle River, New Jersey.

Holou RAY, Stevens G, Kindomihou V (2011) Impact of nitrogen fertilization on nutrient removal by corn grain. Crop Manag 10(1):1-9

Hosseinzadeh SR, Ahmadpour R (2018) Evaluation of vermicompost fertilizer application on growth, nutrient uptake and photosynthetic pigments of lentil (Lens culinaris Medik.) under moisture deficiency conditions. J Plant Nutr 41(10):1276-1284

Hunter MC, Smith RG, Schipanski ME, Atwood LW, Mortensen DA (2017) Agriculture in 2050: recalibrating targets for sustainable intensification. Bioscience 67(4):386-391

Jiang W, Liu X, Qi W, Xu X, Zhu Y (2017) Using QUEFTS model for estimating nutrient requirements of maize in the Northeast China. Plant Soil Environ 63(11):498-504

Jie C, Jing-zhang C, Man-zhi T, Zi-tong G (2002) Soil degradation: a global problem endangering sustainable development. J Geogr Sci 12:243-252

Kader MA, Yeasmin S, Solaiman ZM, De Neve S, Sleutel S (2017) Response of hydrolytic enzyme activities and nitrogen mineralization to fertilizer and organic matter application in subtropical paddy soils. Eur J Soil Biol $80: 27-34$

Khan KS, Joergensen RG (2009) Changes in microbial biomass and P fractions in biogenic household waste compost amended with inorganic $P$ fertilizers. Bioresource Technol 100:303-309

Khan A, Lu G, Ayaz M, Zhang H, Wang R, Lv F, Yang X, Sun B, Zhang S (2018) Phosphorus efficiency, soil phosphorus dynamics and critical phosphorus 
level under long-term fertilization for single and double cropping systems. Agric Ecosyst Environ 256:1-11

Ladha JK, Reddy PM (2003) Nitrogen fixation in rice systems: state of knowledge and future prospects. Plant Soil 252(1):151-167

Liang Q, Chen HQ, Gong YS, Fan MS, Yang HF, Lal R, Kuzyakov Y (2012) Effects of 15 years of manure and inorganic fertilizers on soil organic carbon fractions in a wheat-maize system in the North China Plain. Nutr Cycl Agroecosyst 92:21-33

Liu Z, Rong Q, Zhou W, Liang G (2017) Effects of inorganic and organic amendment on soil chemical properties, enzyme activities, microbial community and soil quality in yellow clayey soil. PLoS ONE 12(3):e0172767

Machado CTDT, Furlani AMC (2004) Kinetics of phosphorus uptake and root morphology of local and improved varieties of maize. Sci Agric 61(1):69-76

Mahmood F, Khan I, Ashraf U, Shahzad T, Hussain S, Shahid M, Abid M, Ullah $S$ (2017) Effects of organic and inorganic manures on maize and their residual impact on soil physico-chemical properties. J Soil Sci Plant Nut 17(1):22-32

Mariano JA, Yniguez TM, Aguas EH (1955) Soil survey of Bukidnon Province, The Philippines with a discussion on the chemical characteristics and fertilizer requirements of the soils in Bukidnon Province. Soils Report 21. Manila, The Philippines: Department of Agriculture and Natural Resources

Malik MA, Marschner P, Khan KS (2012) Addition of organic and inorganic P sources to soil—effects on P pools and microorganisms. Soil Biol Biochem 49:106-113

Masclaux-Daubresse C, Daniel-Vedele F, Dechorgnat J, Chardon F, Gaufichon L, Suzuki A (2010) Nitrogen uptake, assimilation and remobilization in plants: challenges for sustainable and productive agriculture. Ann BotLondon 105:1141-1157

Mengel K, Kirkby EA (1987) Principles of Plant Nutrition. International Potash Institute, Berne

Menta C (2012) Soil fauna diversity_Function, soil degradation, biological indices, soil restoration. Biodiversity Conservation and Utilization in a Diverse World. Intech, p 284.

Moe K, Htwe AZ, Thu TTP, Kajihara Y, Yamakawa T (2019) Effects on NPK status, growth, dry matter and yield of rice (Oryza sativa) by organic fertilizers applied in field condition. Agriculture 9:109

Mosier AR, Bleken MA, Chaiwanakupt P, Ellis EC, Freney JR, Howarth RB, Matson PA, Minami K, Naylor R, Weeks KN, Zhu ZL (2002) Policy implications of human-accelerated nitrogen cycling. In The nitrogen cycle at regional to global scales. Springer, Dordrecht, pp 477-516

Muktamar Z, Sudjatmiko S, Chozin M, Setyowati N, Fahrurrozi M (2017) Sweet corn performance and its major nutrient uptake following application of vermicompost supplemented with liquid organic fertilizer. Int J Adv Sci Eng Inf Technol 7(2):10

Mullins CE, Young AG, Bengough AG, Ley GJ (1987) Hard-setting soils. Soil Use Manag 3:79-83

Mullins CE, MacLeod DA, Northcote KH, Tisdall JM, Young IM (1990) Hardsetting soils: behaviour, occurrence and management. In: Lal R, Stewart BA (eds) 'Soil degradation'. Advances in Soil Science No. 11, pp 37-108.

Mullins CE (1997) Hardestting. In: Lal R, Blum WH, Valentin C, Stewart BA (eds) Methods of assessment of soil degradation. CRC Press, Boca Raton, FL, pp 109-128

Mullins CE (1999) Hardsetting soils. In: Sumner ME (ed) Handbook of soil science. CRC Press, New York, pp G65-G87

Naseer A, Pandey P (2018) Assessment and monitoring of land degradation using geospatial technology in Bathinda district, Punjab. India Solid Earth $9(1): 75$

Nosalewicz A, Lipiec J (2014) The effect of compacted soil layers on vertical root distribution and water uptake by wheat. Plant Soil 375:229-240

Ogg CL (1960) Determination of nitrogen by the micro-Kjeldahl method. Assoc Offic Ag Chem J 43:689-693

Olk D, Cassman K, Simbahan G, Sta. Cruz PC, Abdulrachman S, Nagarajan R, Tan SP, Satawathananont S (1998) Interpreting fertilizer-use efficiency in relation to soil nutrient-supplying capacity, factor productivity, and agronomic efficiency. Nutr Cycling Agroecosyst 53:35-41

Palm CA, Giller KE, Mafongoya PL, Swift MJ (2001) Management of organic matter in the tropics: translating theory into practice. Nutr Cycl Agroecosyst 61:63-75

PCARRD (1991) Standard methods of analysis for soil, plant tissue, water and fertilizer. PCARRD, Los Baños
PCARRD (2006) The Philippine recommends for soil fertility management. Philippine Recommends Series No-36-D. Los Banos, Laguna, The Philippines: Philippine Council for Agriculture, Forestry, and Natural Resources Research and Development, Department of Science and Technology.

Penn CJ, Camberato J (2019) A critical review on soil chemical processes that control how soil pH affects phosphorus availability to plants. Agriculture 9:120

Postma JA, Dathe A, Lynch JP (2014) The optimal lateral root branching density for maize depends on nitrogen and phosphorus availability. Plant Physiol 166:590-602

Puli MR, Prasad PRK, Jayalakshmi M, Rao BS (2017) Effect of organic and inorganic sources of nutrients on NPK uptake by rice crop at various growth periods. Res J Agric Sci 8(1):64-69

Ren F, Zhang X, Liu J, Sun N, Sun Z, Wu L, Xu M (2018) A synthetic analysis of livestock manure substitution effects on organic carbon changes in China's arable topsoil. CATENA 171:1-10

Sarker UK, Uddin MR, Sarkar MAR, Salam MA, Khairul A (2017) Influence of organic and inorganic nitrogen on the growth and yield of irrigated rice. Asian-Aus J Biosci Biotech 2:9-23

Sastre B, Marques MJ, García-Díaz A, Bienes R (2018) Three years of management with cover crops protecting sloping olive groves soils, carbon and water effects on gypsiferous soil. CATENA 171:115-124

Schenk MK, Barber SA (1979) Root characteristics of corn genotypes as related to P uptake. Agron J 71:921-924

Scotti R, Bonanomi G, Scelza R, Zoina A, Rao MA (2015) Organic amendments as sustainable tool to recovery fertility in intensive agricultural systems. J Soil Sci Plant Nut 15(2):333-352

Seleiman MF, Santanen A, Stoddard FL, Mäkelä PSA (2012) Feedstock quality and growth of bioenergy crops fertilized with sewage sludge. Chemosphere 89:1211-1217

Seleiman MF, Santanen A, Jaakkola S, Ekholm P, Hartikainen H, Stoddard FL, Mäkelä PSA (2013) Biomass yield and quality of bioenergy crops grown with synthetic and organic fertilizers. Biomass Bioenerg 59:477-485

Seleiman MF, Abdelaal MS (2018) Effects of organic, inorganic and bio-fertilization on growth, yield and quality traits of some chickpea (Cicer arietinum L.) varieties. Egypt J Agron 40(1):105-117

Seleiman MF, Kheir AS (2018) Maize productivity, heavy metals uptake and their availability in contaminated clay and sandy alkaline soils as affected by inorganic and organic amendments. Chemosphere 204:514-522

Seleiman MF, Kheir AMS, Al-Dhumri S, Alghamdi AG, Omar ESH, Aboelsoud HM, Abdella KA, Abou El Hassan WH (2019) Exploring optimal tillage improved soil characteristics and productivity of wheat irrigated with different water qualities. Agronomy 9(5):233

Seleiman MF, Santanen A, Mäkelä PSA (2020) Recycling sludge on cropland as fertilizer - advantages and risks. Resour Conserv Recy 155:104647

Seleiman MF, Almutairi KF, Alotaibi M, Shami A, Alhammad BA, Battaglia ML (2021) Nano-fertilization as an emerging fertilization technique: why can modern agriculture benefit from its use? Plants 10(1):2

Selim MM (2020) Introduction to the integrated nutrient management strategies and their contribution to yield and soil properties. Int J Agron 20:1-14

Sharma NK, Singh RJ, Kumar K (2012) Dry matter accumulation and nutrient uptake by wheat (Triticum aestivum L.) under poplar (Populus deltoides) based agroforestry system. ISRN Agron 5:1-7

Sherrell CG (1970) Comparison of chemical extraction method for the determination of "available" phosphate in soils. I. Correlations between methods and yield and phosphorus uptake by white clover grown on 16 North Island soils in the glasshouse. New Zeal J Agr Res 40:559-567

Singh A, Kumar A, Jaswal A, Singh M, Gaikwad DS (2018) Nutrient use efficiency concept and interventions for improving nitrogen use efficiency. Plant Arch 18(1):1015-1023

Singh D, Lenka S, Lenka NK, Trivedi SK, Bhattacharjya S, Sahoo S, Saha JK, Patra AK (2020) Effect of reversal of conservation tillage on soilnutrient availability and crop nutrient uptake in soybean in the vertisols of central India. Sustainability 12:6608

Tahat MM, Alananbeh KM, Othman YA, Leskovar DI (2020) Soil health and sustainable agriculture. Sustainability 12:4859

Tan ZX, Lal R, Wiebe KD (2005) Global soil nutrient depletion and yield reduction. J Sust Agric 26:123-146 
Thompson H (2012) Food science deserves a place at the table-US agricultural research chief aims to raise the profile of farming and nutrition science. Nature, July, 12.

Tilahun-Tadesse F, Nigussie-Dechassa R, Bayu W, Gebeyehu S (2013) Effect of farmyard manure and inorganic fertilizers on the growth, yield and moisture stress tolerance of rain-fed lowland rice. Am J Res Com 1(4):275-301

Wang X, Cai D, Hoogmoed WB, Perdok UD, Oenema O (2007) Crop residue, manure and fertilizer in dryland maize under reduced tillage in northern China: I grain yields and nutrient use efficiencies. Nutr Cycl Agroecosyst 79:1-16

Young IM, Mullins CE, Costigan PA, Bengough AG (1991) Hardsetting and structural regeneration in two unstable Britsh sandy loams and their influence on crop growth. Soil Till Res 19:383-394

Yousaf M, Li J, Lu J, Ren T, Cong R, Fahad S, Li X (2017) Effects of fertilization on crop production and nutrient-supplying capacity under rice-oilseed rape rotation system. Sci Rep 7:1270
Zhao S, Xu X, Wei D, Lin X, Qiu S, Ciampitti I, He P (2020) Soybean yield, nutrient uptake and stoichiometry under different climate regions of northeast China. Sci Rep 10:8431

Zhu ZL, Chen DL (2002) Nitrogen fertilizer use in China - contributions to food production, impacts on the environment and best management strategies. Nutr Cycling Agroecosyst 63:117-127

\section{Publisher's Note}

Springer Nature remains neutral with regard to jurisdictional claims in published maps and institutional affiliations.

\section{Submit your manuscript to a SpringerOpen ${ }^{\circ}$ journal and benefit from:}

- Convenient online submission

- Rigorous peer review

- Open access: articles freely available online

- High visibility within the field

- Retaining the copyright to your article

Submit your next manuscript at $\boldsymbol{\nabla}$ springeropen.com 